Article

\title{
Citizen Relationship Management System Users' Contact Channel Choices: Digital Approach or Call Approach?
}

\author{
Wei-Ning Wu \\ Institute of Public Affairs Management, National Sun Yat-sen University, Kaohsiung 80424, Taiwan; \\ weiningwu@mail.nsysu.edu.tw; Tel.: +886-7-52525000 (ext. 4917) \\ Academic Editor: Muneo Kaigo \\ Received: 1 September 2016; Accepted: 16 December 2016; Published: 5 January 2017
}

\begin{abstract}
Many municipal governments adopted 311 decades ago and have advocated access equality in citizens' use of 311. However, the role of citizens in the development and usage of 311 remains limited. Channel choices have been discussed in various types of governmental information and communication technologies (ICTs), especially when the innovative technology has just been adopted. Much has supported the idea that 311 is viewed as a method of digital civic engagement that many municipal governments adopt to maintain citizen relationship management and the capacity for government service delivery. However, we are still unclear about how citizens use it. This study applies the theory of channel expansion to examine how San Francisco residents use the 311 system, and how citizens' technology experiences impact their 311 digital contact channel choices rather than the 311 hotline contact channel choice. In addition, we discuss major issues in citizens' 311 contact choices, so that 311 municipal governments may draw lessons from the San Francisco experience.
\end{abstract}

Keywords: digital citizenry; citizen relationship management; digital divide; 311

\section{Introduction}

Public officials are concerned about citizen satisfaction and have tried to create strategies to enhance positive citizen relationship management [1]. The 311 system is a well-known citizen relationship management tool that many local governments have adopted in the United States. Since 1996, some local governments have adopted a 311 hotline service for non-emergency citizen requests. Although the 311 hotline service has been around for several years, recent advances in the electronically-based 311 service have allowed governments to develop 311 websites or Open311 forums that function as mutual communication between citizens and public officials and have a variety of online materials for those who can search by themselves [2,3]. As more and more municipal governments pay attention to the use and development of 311,311 in selected municipalities has combined a 311 hotline system with citizen relationship management mechanisms and e-government services in US municipalities [4]. For example, Denver's 311 Call Center for the City and County of Denver, a proud recipient of the Public Technology Institute's Citizen Engaged Community Award from 2011 to 2014, adopted the 311 hotline in 2006 and set up a 311 mobile application for citizens' mobile devices to access the Denver 311 mobile website in 2010.

Similarly, the City and County of San Francisco (SF) started using the 311 system in 2007 and developed a 24/7 (twenty-four hours seven days a week) Customer Service Center after installing e-government mechanisms, such as city Twitter accounts and the Mobile SF311 App, and performance and data management mechanisms for Citizen Relationship Management(CRM) in the following years. In these cases, the comprehensive customer service of 311 is viewed as an advanced and innovative technology for local governments and a method of digital civic engagement. The advent of the Internet 
and the development of information and communication technologies (ICTs)—electronic contact channels advocated as an alternative for citizens because of their high-speed functions and capacity to store more information-has led to a more efficient communication approach than the traditional offline contact channels [3].

Governments have invested much in developing electronic service channels since the 1990s [5,6]. Many citizens, public officials, and political leaders are interested in the adoption of innovative ICTs in government. However, efforts to do so are currently underway around the world. There is significant evidence to propose that these efforts are not as effective as expected. Some efforts appear to be unproductive because of improper technology planning or implementation [7]. Other efforts fail to provide access to each citizen because of the digital divide among various groups of the public, which leads to a low technology usage rate and limits citizen-initiated contact and the participatory willingness of citizen groups [8-11]. In order to expand the range of citizens' government ICT use, governments have considered various contact channel strategies to interact with citizens. Hence, different groups of citizens can have the option to conduct citizen-initiated contact through traditional offline contact methods or through digital contact methods [12-15].

Due to the fact that citizens have choices between a traditional 311 hotline and a 311 digital approach, we need to know more citizens' 311 use behaviors. The choice of channel when using 311 is the type of citizen 311 use behaviors that scholars and practitioners have been concerned with, but it has not examined empirically. Hence, this study points out the research question: why do 311 users use digital contact approaches rather than traditional offline call contact approaches? This study concentrates on elaborating on factors that serve as causal drivers of digital channel choices. The 2011 San Francisco dataset is used to test three hypotheses derived from the channel expansion theory which argues that the factors of online public service use behavior; the perception of 311 information richness; and learning about 311 via friends, colleagues, or a community group are significant in affecting individual technology channel choices [16-18].

\section{Literature Review}

Studies has shown that citizen interactions with public officials have been gradually switching from traditional offline contact to online/digital contact [19]; the evidence has also shown that local governments have tried to enhance the use of the Internet or related digital technology to communicate and deliver policy information to their citizens. As a result, the citizens' usage of web channels to contact public officials has grown [4]. Reddick [6] echoed the findings of Wang's 2001 [4] study and examined the growth of Internet-oriented citizen interactions with the government. He argued that the social demographic, citizens' political attitudes toward the government, and the purpose of citizens' interactions all influenced citizens' preferences for web contact channels. However, Reddick [20] only focused on the use of web contact channels at the individual level and did not focus on the channel choice among multiple channel approaches.

Some studies of contact channel choice have explored differences in citizen-initiated contact with public officials through the use of phones and websites. Thomas and Streib [21] examined the usage of the web approach and the traditional approach of citizen-initiated contacts with the government through a random telephone survey of Georgia residents and the determinant of frequent use of government web sites. They found that citizen-initiated web contact with the government supplements traditional citizen-initiated contact, and the number of citizens who use the web to conduct citizen-initiated contact with the government has increased. Thomas and Streib [21] also found that a digital divide has existed between residents that conducted web-based citizen-initiated contact and residents that conducted call approach citizen-initiated contact. Race, income, education, and age were the factors in the digital divide of conducting citizen-initiated contacts with the government. Specifically, white younger citizens with a high income and education level would be more likely to conduct web-based citizen-initiated contact. 
Reddick [22] compared the differences between two types of citizen-initiated contacts with the government: phones and websites. Similar to the findings of Thomas and Streib [21], Reddick supported the idea that citizen contact channel choices depend on the characteristics of the task. That is, citizens prefer to use the phone to contact governments for problem solving, whereas they prefer to use websites to contact governments for information searches and business transactions. In addition, Reddick found that individual differences are the main factors in contact channel choice with governments.

Ebbers, Pieterson, and Noordman [23] observed the difference between the organization-centric view and the citizen-centric view of contact channels and asserted that a gap exists between citizens' actual preferences for contact channels and the views of public officials about the ways that citizens use the contact channels. Governments' channel preferences are based on considerations of cost and efficiency, but task characteristics, individual differences, and situational reasons guide citizens' channel preferences. Although governments have emphasized the development of government ICTs and have persuaded citizens to use electronic contact channels to contact governments, most citizens still prefer to use traditional access channels, such as in-person (a front desk encounter) or telephone-based approaches, to contact governments.

Pieterson and van Dijk [6] explored the determinants of channel choice of citizen-oriented contacts through a qualitative method. They combined the main factors that influence citizen contact channel decisions, including habits, channel use experience, individual socio-demographical factors, situational constraints, and task features. Pieterson and Dijk found that users' habits were the main factor in channel choice determination, and the purpose and complexity of the task was second.

In addition, studies have found that the quality of the contact channel was the main factor influencing the citizens' contact channel choices [24]. Schellong and Mans [20] asserted that citizens prefer to choose the contact channel with an integrated government service because they consider the decrease in cost relative to information, communication, and transaction. For the latest study of contact channel choices between traditional and electronic contact channels, Reddick, Abdelsalam, and Elkadi [25] examined the case of Egypt and found that the digital access divide and socio-demographic digital divide both have a strong relationship to contact channel choices.

Generally speaking, the gap in the literature for the question about citizen 311 contact channel choice has concerned which factors influence 311 contact channel choice at the individual level, because 311 is a CRM system that many municipalities have only started adopting this decade. Current research has asserted that the use of digital CRM technologies has had a positive impact on citizens' contact with public officials $[2,26,27]$. However, the major issues of the use of information technology are the questions about how digital technologies enhance who contacts public officials and for what reasons: the issues of "who and why" strongly influence information delivery and communication between citizens and public officials as well as the decision-making and planning of public policies [19].

To summarize, the literature dealing with citizen channels for e-government is somewhat scarce. The concept of contact channel choice emphasizes that the individual differences impact ICT users in their choice of a specific channel to contact governments in various digital-enabled environments [28-30]. Governments have developed a multitude of contact channels at their disposal for interaction with the people, and citizens are able to have multiple contact choices based upon the situation they face and the mix of experiences that they have had. Public service consumers would develop multi-channel behaviors when they experience a dynamic environment or are exposed to the digital environment $[25,31,32]$. Some of these studies emphasize greater actual use and the purpose for citizens' e-government contacts. However, no empirical study explores the contact channel choices regarding 311 at the local level. Hence, this study examines the influence of individual differences on the choice of 311 contact channel and fills the gap of ICT studies in the field of public administration.

The origin of the digital 311 contact approach dates back to 2010 when the Federal Communication Commission (FCC) spawned 311 as a comprehensive citizen relationship management system, including the call approach and the digital approach through ICT integration within a selected 
municipality. In San Francisco, 311 offers offline and digital contact methods to citizens [33]. Public officials would prefer that citizens use 311 digital contact approaches, because public agencies can easily collect citizen information, such as the location of the information source and the type of request. The argument for the digital contact channel choice emphasizes the asynchronous nature of technology devices for users. Each connection between citizens and public officials allowed information delivery and mutual information exchange in an efficient manner. Importantly, multiple individuals and stakeholders can deliver information at the same time. Unlike the telephone, which requires at least two parties to be simultaneously on the line for communication or a transaction, digital 311 allows individual citizens to deliver information and conduct transactions without the limitations of time and space [2].

Also, the digital contact approach allows public agencies to have more time and space to respond to citizens' requests as compared to the offline contact approach, which requires a public official to take citizens' requests simultaneously and to have a satisfactory answer or at least a quality response to citizens' needs. However, citizens have choices between 311 offline contact approaches and digital contact approaches. They use a specific contact approach based upon their preference, consideration, or technology richness [34]. The difference between offline phone contact approaches and online digital contact approaches existed when digital CRM-based 311 was first adopted [33,35].

\section{Research Model Development and Hypotheses}

In discussing the adoption of the ICT-oriented approach at an individual level, this study would apply the channel expansion theory to examine behaviors and citizens' 311 mode choices between the traditional call approach and the digital ICT-oriented approach. Because of a lack of ICT knowledge and a high level of uncertainty in using new technology, some groups of individuals encounter obstacles to initial ICT usage $[3,36,37]$. When talking about the channel choice between traditional and electronic contact channels, individual digital use behavior and individual technology knowledge have a strong relationship to channel choice [30,38-41].

Channel expansion theory has been applied to communication and technology use at the individual level. Channel expansion theory emphasizes individuals' perceptions toward their intention regarding technology use and their actual use, and how relative technology experiential factors impact individuals' perceptions of media/technology richness [42]. Individuals have limited information and abilities to predict and explicate new technology use. Users' varying perceptions of any ICTs are dependent on their knowledge-building experiences with related technologies. The knowledge-building experiences of users with similar technology—or technologies with the same functions with an innovation-influence channel choices and adoption [16].

Certain users' experiences with technology have helped them develop an attitude of richness toward the channel choices $[43,44]$. Four main information and communication technology use experiences are identified from channel expansion theory, including: experience with specific channels, experience with various types of messaging, experience with the organizational context or environment, and experience with other communication participants.

This study applies channel expansion theory and argues that access to 311 technology (experience with other communication participants) and information-seeking behaviors of library e-services (experience with public organizations' digital channels) can explain 311 users' digital contact behaviors.

\subsection{Online Public Service Use Behavior}

Chancel choice is mainly impacted by the combined result from the differences in access, competence (skill), and motivation. Generally, these differences mainly include users' characteristics, needs, perspectives, and previous experiences. Importantly, choosing a specific method in using digital technology shapes the attitudes that an individual develops toward technology richness as well as acceptance of new technology and use behaviors [16,45]. 
Individual development of a richness attitude is contingent upon users' experiences, which mainly include experiences with specific channels, experiences with various types of messaging, experiences with the organizational context or environment, and experiences with other communication participants. For the use of a new technology, the early adopter of a new technology plays a key role in the technology diffusion process, due the fact that they are able to respond to the concerns and uncertainty of using the new technology with a positive message [45].

However, at the beginning stage, the use behavior of the early adopter is shaped by their user behavior in other digital services or technologies because of the decrease of uncertainty and transaction costs in using new technology. Hence, individuals' frequent use of online public services would accumulate digital technology richness in other digital public services. Also, an individual's digital technology user behavior in one ICT would duplicate this behavior mode to other types of ICTs, especially when a new ICT is just adopted [25,46]. When a digital service, such as a 311 system with both a traditional calling approach and a digital approach, is adopted, at the beginning individuals are more likely to choose the digital approach because their digital public service use experiences decrease their uncertainty to new digital approaches and tell them the digital approach is associated with convenience, accessibility, and the richness of their previous online service use. Hence, this study hypothesizes that:

H1: An increase in frequent online public service use is associated with an increase in the usage of the 311 digital contact channel service.

\subsection{Perception of 311 Information Richness}

Channel expansion theory mainly focuses on the information richness of technology use, which is prior knowledge-building technology use experiences, and how it can explain individuals' technology use and choices. Compared to the offline 311 call contact approach, the 311 digital contact approach is more innovative and new for many people, and government technology leaders could use various methods to educate and encourage citizens to contact them online [46]. Studies have shown that the general public in America mostly has positive perspectives on digital technologies that the government has adopted. However, the adoption of a new technology creates uncertainty for individual users. The uncertainty and cost of using a new technology will decrease if the individual learns more about the specific technology. More information about the use of an innovative technology leads individuals to have more awareness of the adoption of the new technology and, in turn, leads to changing views about the new technology usage and its influence on the individual's daily life as well as actual utilization $[2,11,25]$. Hence, this study hypothesizes that:

H2: An increase in the awareness of 311 is associated with an increase in the usage of the 311 digital contact channel service rather than the 311 offline contact channel.

\subsection{Information Sources Related to 311}

Information sources of governmental ICTs have been the main concerns of public managers, and many governmental ICTs fail due to the fact that citizens have less awareness of the selected governmental ICTs [30]. Individuals' awareness of innovation may be influenced by information quality and quantity and by the citizens' use of governmental ICTs. Information quality mainly refers to the quality of the content in an emergency situation (e.g., an earthquake) and a routine situation (e.g., a non-emergency service request). On the other hand, information quantity is related to how and where citizens hear about as well as learn about a new ICT; it mainly focuses on the technology information sources, the quantity of messages regarding the intention of using selected ICTs, or the actual use, as well as the frequency of using selected ICTs [47].

Importantly, technology information sources have been weighted differently in individual technology use [19,23]. In most cases, individuals become early technology adopters because they 
learned about the adoption of a new technology from social media, friends, colleagues, or community groups [48]. Among these technology information sources, interpersonal and informal means (e.g., from family, friends, colleagues, and community groups) have the greatest potential to influence individual technology use $[49,50]$. Hence, this study hypothesizes that:

H3: The citizens who learn of 311 from their friends, family members, or colleagues are more likely than those who do not to use the 311 digital contact channel.

\section{Research Method}

\subsection{Survey Data Collection}

For testing the factors influencing citizens' 311 contact channel choices, the 2011 Citizen Survey of the City and County of San Francisco was used. The survey data represents citizens' perceptions about 311 use and the performance of selected public services as well as the social demographic and socioeconomic background of survey responders. The sample consists of individual citizens residing in San Francisco. The survey of the City and County of San Francisco was administered by the ETC Institute in May and June 2011. The survey was given in three languages-English, Spanish, and Chinese-and San Francisco residents could complete the survey through mail, on the phone, or on the web. Approximately 1000 residents were selected randomly from each supervisorial district, and the response rate was about $37 \%$ when the ETC Institute did not account for undeliverable surveys. The data consists of 3979 randomly selected citizens in San Francisco. However, the data sample in this study consists of 1113 citizens who had a 311 use experience in the City of San Francisco.

\subsection{Measurements}

Table 1 represents the details about the measurements of all variables. The dependent variable in the analysis is whether 311 users make contact through a digital approach or not. Citizens' 311 contact channel choice is measured by whether 311 users use 311 to contact the San Francisco city government through a digital approach or not. The variable is a dummy variable containing the question, "Have you contacted 311 by the web or a mobile device during the past year?" If the survey respondents indicated that they had, the variable was coded as " 1 ". If the respondent indicated that they had not, the variable was coded as " 0 ", which means the respondent chose to use the 311 calling approach.

The main independent variables include online public service use behavior and information sources related to 311. Online public service use behavior is operationalized by the citizens' responses regarding the frequency of their use of online library services (websites including catalogs, databases, calendars, etc.). The citizens were asked to "indicate the frequency [they] visited or used the online library service during the past year". There are five degrees of frequency of use of public services: at least once a week (coded as " 4 "), at least once a month (coded as " 3 "), several times a year (coded as “2"), once or twice a year (coded as " 1 "), and never (coded as " 0 ").

The perception of 311 information richness is measured by the five sources for learning about 311: a brochure or poster, radio or TV, a friend or colleague, community group, and other. The citizens were asked to indicate where they learned about 311 use. In the first model, the authors added the five information sources for 311 and made a variable titled "perception of 311 information richness". There are five degrees of awareness of 311: no information source for 311 (coded as " 0 ") to five information sources for 311 (coded as " 5 "). In the second model, the author combined the information source variables "friend or colleague" and "community group" and named the combination "learn about 311 via friends, colleagues, or a community group". Moreover, adding a dummy variable of "accessed 311 information via social networking", another variable ("learn about 311 via TV or Radio") can be used to compare the differences in the sources of information related to 311 in 311 users' channel choices. 
Table 1. Summary of indicator measurements.

\begin{tabular}{|c|c|}
\hline Variables & Measurement \\
\hline \multicolumn{2}{|r|}{ Dependent Variable } \\
\hline Digital 311 channel choice & $\begin{array}{l}\text { Whether } 311 \text { users contact the SF government via digital approach } \\
\text { (digital approach =1). }\end{array}$ \\
\hline \multicolumn{2}{|r|}{ Independent Variables } \\
\hline Online public service use behavior & $\begin{array}{l}\text { Citizen response of their frequent use of online library services } \\
\text { (At least once a week }=4 \text {, At least once a month }=3 \text {, Several times } \\
\text { a year }=2 \text {, Once or twice a year }=1 \text {, and Never }=0 \text { ). }\end{array}$ \\
\hline Perception of 311 information richness & $\begin{array}{l}\text { Sources of detail contained in a piece of } 311 \text { technology learning } \\
\text { information }(0-5) \text {. }\end{array}$ \\
\hline $\begin{array}{l}\text { Learn about } 311 \text { via friends, colleagues, } \\
\text { or a community group }\end{array}$ & $\begin{array}{l}\text { Citizen response: do they learn about } 311 \text { via friends, colleagues, } \\
\text { or a community group (Yes }=1) \text {. }\end{array}$ \\
\hline Learn about 311 via TV or radio & Citizen response: do they learn about 311 via TV or radio (Yes $=1$ ). \\
\hline \multicolumn{2}{|r|}{ Control Variables } \\
\hline Gender & Citizen response to their gender $($ Male $=1)$. \\
\hline Age & Age group $(18-34=1,35-44=2,45-54=3,55-64=4$, and $65+=5)$. \\
\hline Income & $\begin{array}{l}\text { Income (less than } \$ 10,000=1, \$ 10,000 \text { to } \$ 24,999=2, \$ 25,000 \text { to } \\
\$ 49,999=3, \$ 50,000 \text { to } \$ 99,999=4 \text {, and } \$ 100,000 \text { or more }=5 \text { ). }\end{array}$ \\
\hline Education & $\begin{array}{l}\text { Respondent's highest education completed. }(\text { Less than high } \\
\text { school = 1; High school = 2; Less than four years of college = } 3 \text {; } \\
\text { Four or more years of college/Post graduate }=4 \text { ). }\end{array}$ \\
\hline Race & $\begin{array}{l}\text { Citizen response to their race. White } / \text { Caucasian }=1 \text {, Asian or } \\
\text { Pacific Islander }=2 \text {, Latino } / \text { Hispanic }=33 \text {, the Black }=4 \text {, } \\
\text { and Other }=5 \text {. }\end{array}$ \\
\hline Working status & Employee (Yes = 1). \\
\hline Geographic region of city & Citizens' response of the geographic region of city (Districts 1-11). \\
\hline
\end{tabular}

Control variables mainly include socio-demographic factors, socio-economic factors, working status and the geographic region of the city. Their measurements in this study are as follows: (1) Gender is measured by the citizens' responses to a question about their gender. Male is coded as " 1 ", and female is coded as " 0 "; (2) Education is measured by the citizens' responses to a question about their highest level of formal education. The citizens were asked the question, "What is the highest level of formal education you have completed?" There are four degrees of education: less than high school, high school, less than four years of college, and four years of college or more; (3) Income is measured by the citizens' responses regarding their household's total income before taxes in 2010 . The citizens were asked the question, "What was your household's total income before taxes last year?" There were five degrees of income: less than $\$ 10,000 ; \$ 10,000$ to $\$ 24,999 ; \$ 25,000$ to $\$ 49,999 ; \$ 50,000$ to $\$ 99,999$; and $\$ 100,000$ or more; (4) Age is measured by the citizens' response to a question regarding their age. The citizens were asked the question, "What is your age?" There are five degrees of age: 18-34, 35-44, 45-54, 55-64, and 65+; (5) Race is measured by the citizens' responses to a question about their race. The White/Caucasian group is coded as " 1 ", the Asian or Pacific Islander group is coded as " 2 ", the Latino/Hispanic group is coded as " 3 ", the Black group is coded as " 4 ", and the Other group is coded as " 5 "; (6) Geographic region of the city is measured by the citizens' response regarding the geographic region of the city in which the survey respondent lives. The survey items include 11 geographic regions in San Francisco. The geographic region of the city is a categorical variable, which means that a series of indicator variables of the geographic region of the city would be included in the logistic regression model. For example, if the survey respondents chose district 1 , it was coded as " 1 ". However, this study used the xi command of Stata software to create 10 dummy variables for District 1 
to District 11. Among 11 districts, District 2 is the baseline for the other 10 districts because it has more residents with high socioeconomic status; (7) Working status is measured by the citizens' responses to a question regarding whether a citizen has a job or not. The citizens were asked the question, "How many hours per week do you work in paid employment?" There are four degrees of weekly working hours: none, 1-14 h, 15-34 h, and $35 \mathrm{~h}$ or more. However, the author recoded the variable of working status as a dummy variable: If the survey respondents have a job, it is coded as " 1 ". If not, it is coded as " 0 ".

\section{Results and Analysis}

Table 2 presents the descriptive statistics. For the dependent variables of this study, the variable of "Digital 311 channel choice" has an average of 0.51 , which indicates about $50 \%$ of survey respondents chose the digital 311 contact approach. Table 3 shows the regression estimates in terms of the determinants of the 311 contact channel choice behaviors. The regression estimates support the main theoretical arguments and hypotheses of this research.

Table 2. Descriptive statistics.

\begin{tabular}{cccccc}
\hline Variables & Obs. & Mean & Std. Dev. & Min. & Max. \\
\hline Digital 311 channel choice & 1311 & 0.51 & 0.50 & 0 & 1 \\
Perception of 311 information richness & 1311 & 1.13 & 0.65 & 0 & 5 \\
Learn about 311 via friends, colleagues, & 1311 & 0.34 & 0.47 & 0 & 1 \\
or a community group & 1311 & 0.20 & 0.40 & 0 & 1 \\
Learn about 311 via TV or radio & 1248 & 1.40 & 1.49 & 0 & 4 \\
Online public service use behavior & 1311 & 3.08 & 1.35 & 1 & 5 \\
Age & 1211 & 3.61 & 1.25 & 1 & 5 \\
Income & 1311 & 3.45 & 0.86 & 1 & 4 \\
Education & 1311 & 0.48 & 0.50 & 0 & 1 \\
Gender & $1256(673)$ & 0.53 & 0.50 & 0 & 1 \\
White/Caucasian & $1256(337)$ & 0.26 & 0.44 & 0 & 1 \\
Asian or Pacific Islander & $1256(138)$ & 0.11 & 0.31 & 0 & 1 \\
Latino/Hispanic & $1256(63)$ & 0.05 & 0.22 & 0 & 1 \\
Black & $1256(45)$ & 0.04 & 0.19 & 0 & 1 \\
Other (ethnicity) & $1311(112)$ & 0.09 & 0.29 & 0 & 1 \\
District 1 & $1311(91)$ & 0.07 & 0.25 & 0 & 1 \\
District 2 & $1311(122)$ & 0.09 & 0.29 & 0 & 1 \\
District 3 & $1311(96)$ & 0.07 & 0.26 & 0 & 1 \\
District 4 & $1311(141)$ & 0.11 & 0.31 & 0 & 1 \\
District 5 & $1311(102)$ & 0.08 & 0.27 & 0 & 1 \\
District 6 & $1311(115)$ & 0.09 & 0.28 & 0 & 1 \\
District 7 & $1311(138)$ & 0.11 & 0.31 & 0 & 1 \\
District 8 & $1311(145)$ & 0.11 & 0.31 & 0 & 1 \\
District 9 & $1311(136)$ & 0.10 & 0.31 & 0 & 1 \\
District 10 & $1311(103)$ & 0.08 & 0.27 & 0 & 1 \\
District 11 & 1311 & 0.70 & 0.45 & 0 & 1 \\
Working & & & 0 \\
\hline
\end{tabular}

Note: 1 . The parentheses of each ethnic variable represent the number of survey respondents from each type of ethnicity; 2 . The parentheses of each district variable represent the number of survey respondents from each distric; 3. Obs. = Observation; Std. Dev. = Standard Deviation; Min. = Minimum; Max. = Maximum. 
Table 3. Logistic regression results exploring 311 contact channel choice.

\begin{tabular}{|c|c|c|c|c|c|c|}
\hline & \multicolumn{3}{|c|}{ Model One } & \multicolumn{3}{|c|}{ Model Two } \\
\hline & $\begin{array}{l}\text { Odds } \\
\text { Ratio }\end{array}$ & \multicolumn{2}{|c|}{ Std. Err. } & $\begin{array}{l}\text { Odds } \\
\text { Ratio }\end{array}$ & \multicolumn{2}{|c|}{ Std. Err. } \\
\hline Perception of 311 information richness & 1.76 & 0.43 & ** & & & \\
\hline $\begin{array}{l}\text { Learn about } 311 \text { via friends, colleagues, } \\
\text { or a community group }\end{array}$ & & & & 1.51 & 0.21 & $* * *$ \\
\hline Learn about 311 via TV or radio & & & & 0.85 & 0.14 & \\
\hline Online public service use behavior & 1.09 & 0.05 & ** & 1.11 & 0.05 & ** \\
\hline \multicolumn{7}{|l|}{ Control Variables } \\
\hline Age & 0.72 & 0.04 & $* * *$ & 0.73 & 0.04 & $* * *$ \\
\hline Income & 1.03 & 0.06 & & 1.04 & 0.06 & \\
\hline Education & 0.92 & 0.08 & & 0.91 & 0.08 & \\
\hline Gender & 1.13 & 0.14 & & 1.16 & 0.15 & \\
\hline \multicolumn{7}{|l|}{ Race } \\
\hline $\begin{array}{l}\text { Asian or Pacific Islander } \\
\text { (vs. White/Caucasian) }\end{array}$ & 1.34 & 0.22 & * & 1.39 & 0.23 & $* *$ \\
\hline Latino/Hispanic (vs. White/Caucasian) & 1.04 & 0.24 & & 1.07 & 0.25 & \\
\hline Black (vs. White/Caucasian) & 1.29 & 0.40 & & 1.30 & 0.40 & \\
\hline Other (vs. White/Caucasian) & 0.82 & 0.28 & & 0.87 & 0.30 & \\
\hline \multicolumn{7}{|l|}{ Supervisorial District } \\
\hline District 1 (vs. District 2) & 1.14 & 0.36 & & 1.13 & 0.36 & \\
\hline District 3 (vs. District 2) & 1.31 & 0.38 & & 1.32 & 0.39 & \\
\hline District 4 (vs. District 2) & 0.75 & 0.23 & & 0.79 & 0.25 & \\
\hline District 5 (vs. District 2) & 1.18 & 0.33 & & 1.23 & 0.35 & \\
\hline District 6 (vs. District 2) & 0.69 & 0.21 & & 0.72 & 0.22 & \\
\hline District 7 (vs. District 2) & 0.76 & 0.22 & & 0.75 & 0.22 & \\
\hline District 8 (vs. District 2) & 0.68 & 0.19 & & 0.65 & 0.18 & \\
\hline District 9 (vs. District 2) & 0.81 & 0.22 & & 0.82 & 0.23 & \\
\hline District 10 (vs .District 2) & 1.29 & 0.38 & & 1.35 & 0.40 & \\
\hline District 11 (vs. District 2) & 0.93 & 0.30 & & 0.98 & 0.31 & \\
\hline Working & 1.28 & 0.20 & & 1.28 & 0.20 & \\
\hline Constant & 1.43 & 0.74 & & 2.02 & 0.96 & \\
\hline Number of Obs. & 1113 & & & 1113 & & \\
\hline Log likelihood & -720.61 & & & -718.34 & & \\
\hline LR Chi2 & 100.5 & & $* * *$ & 105.03 & & $* * *$ \\
\hline Pseudo R2 & 0.07 & & & 0.07 & & \\
\hline
\end{tabular}

Note: Std. Err. = Standard Error; ${ }^{* * *} p<0.01 ;^{* *} p<0.05 ;^{*} p<0.10$.

Turning first to Table 3, the effect of information-seeking behaviors (library e-services) is positive on 311 digital contact channel choices in Model One and Model Two (i.e., =1.09, $p<0.05$, and =1.11, $p<0.05$, respectively). There is evidence that citizens who frequently use online services in public libraries, on average, are more likely to use digital 311 contact approaches to contact the city 
government in this study, holding all other variables constant. Model One shows strong evidence that a higher degree of information-seeking behaviors (library e-services) would lead to citizens contacting the government through digital 311 methods. This finding supports Hypothesis 1 in this study.

In Model One, there is evidence that citizens who have a high level of perception of 311 information richness, on average, are more likely to use digital 311 contact approaches to contact the city government than those who have a low level, holding all other variables constant. Model Two shows strong evidence that a greater perception of 311 information richness would more likely lead to citizens contacting the government through digital 311 methods, holding all other variables constant. This finding supports Hypothesis 2 in this study. Specifically, Model Two shows the various influences of 311 information sources and supports and that citizens learn about 311 via friends, colleagues, or a community group. The 311 users who indicated that their technology information sources for 311 are friends, colleagues, or a community group are more likely to use 311 digital contact approaches, holding all other variables constant. This finding supports Hypothesis 3 in this research.

This study also explores the predicted probabilities for the values of online public service use behavior, perception of 311 information richness, and information sources related to 311 through margins. Figures 1-3 provide the prediction of the probabilities of digital 311 contact behavior with $95 \%$ confidence intervals. Figures 1-3 show the statistics and the figures of these three variables (frequent use of public libraries' e-services, perception of 311 information richness, and information sources related to 311) show that the probability of digital 311 contact behavior increases concomitantly with the growth of frequent use of online public libraries, the perception of 311 information richness, and learning about 311 via friends, colleagues, or a community group.

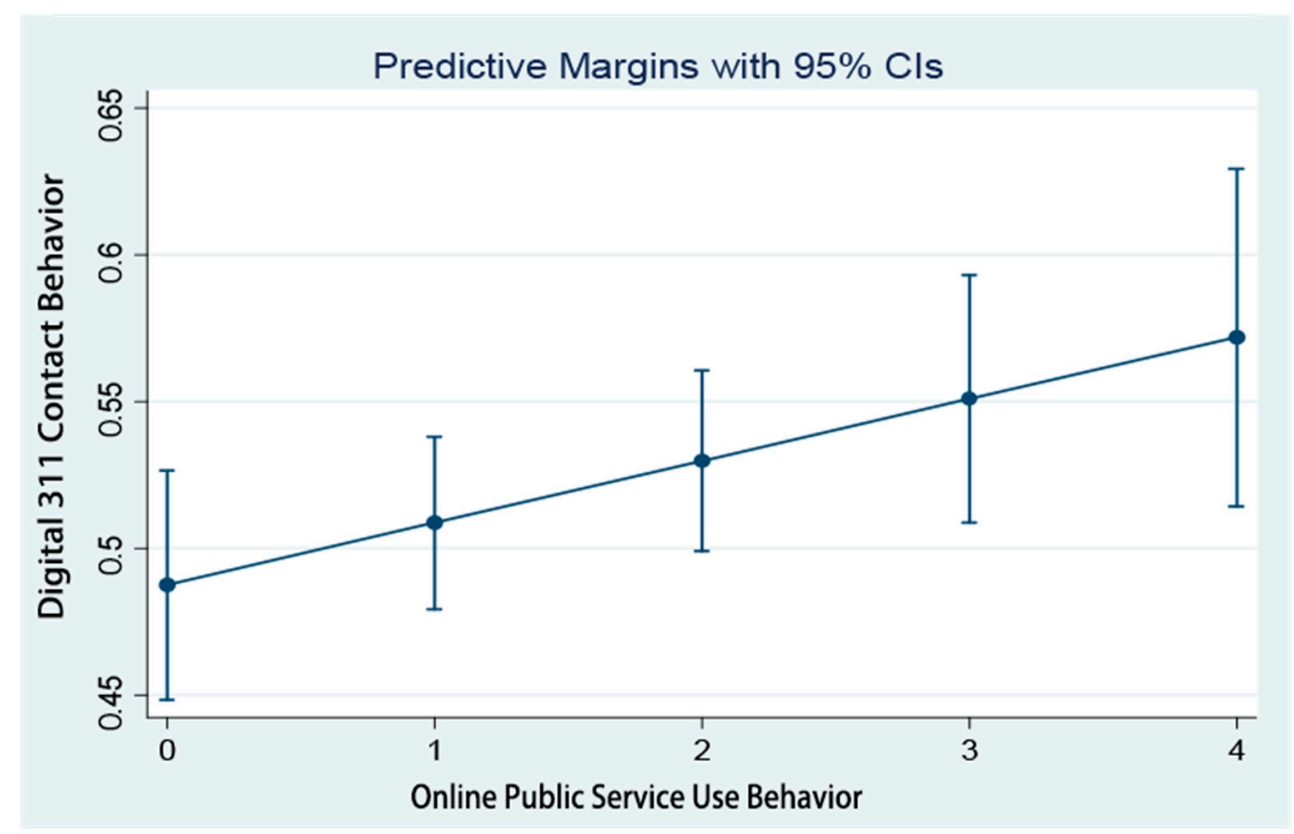

Figure 1. Estimated probabilities of digital 311 contact behavior caused by online public service use behavior. 


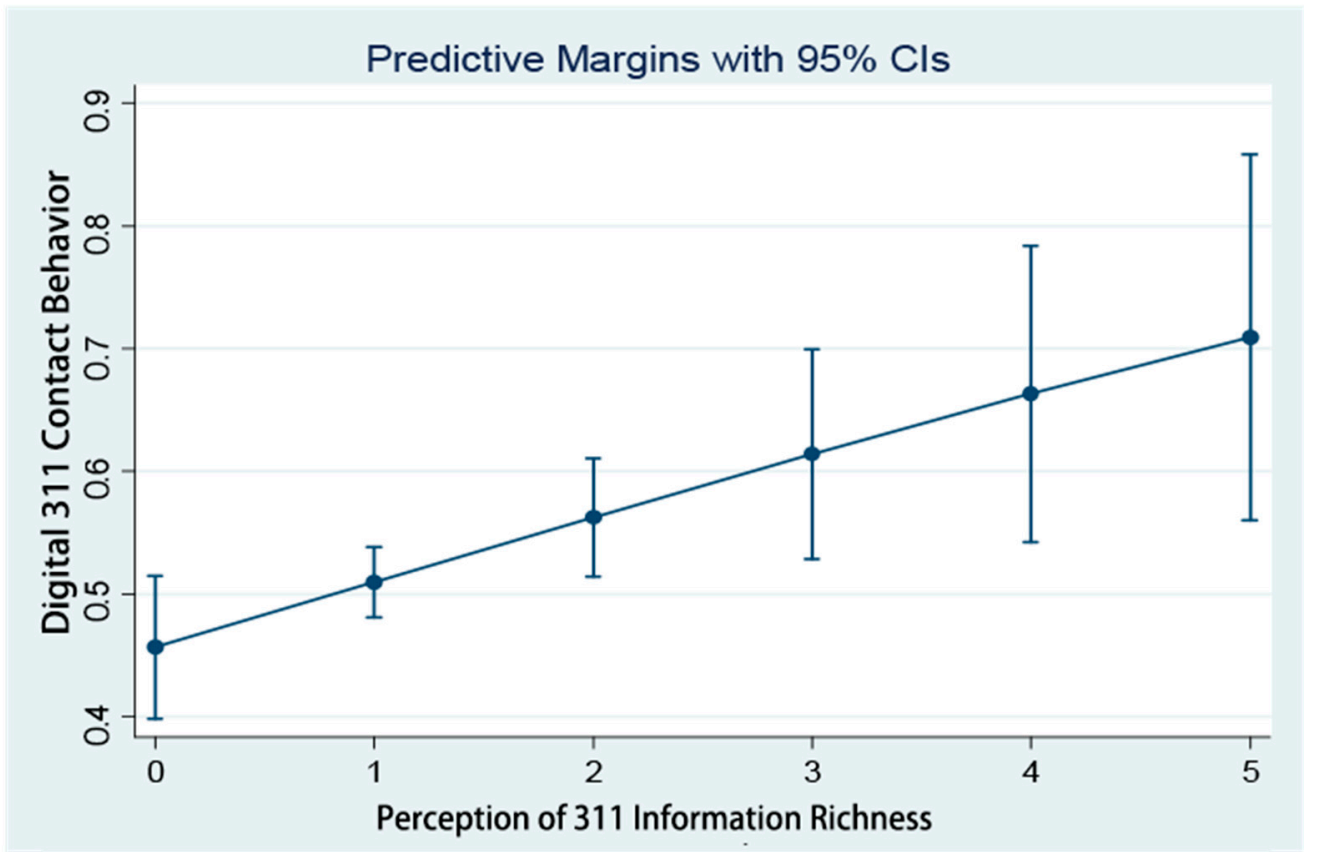

Figure 2. Estimated probabilities of digital 311 contact behavior caused by perception of 311 information richness.

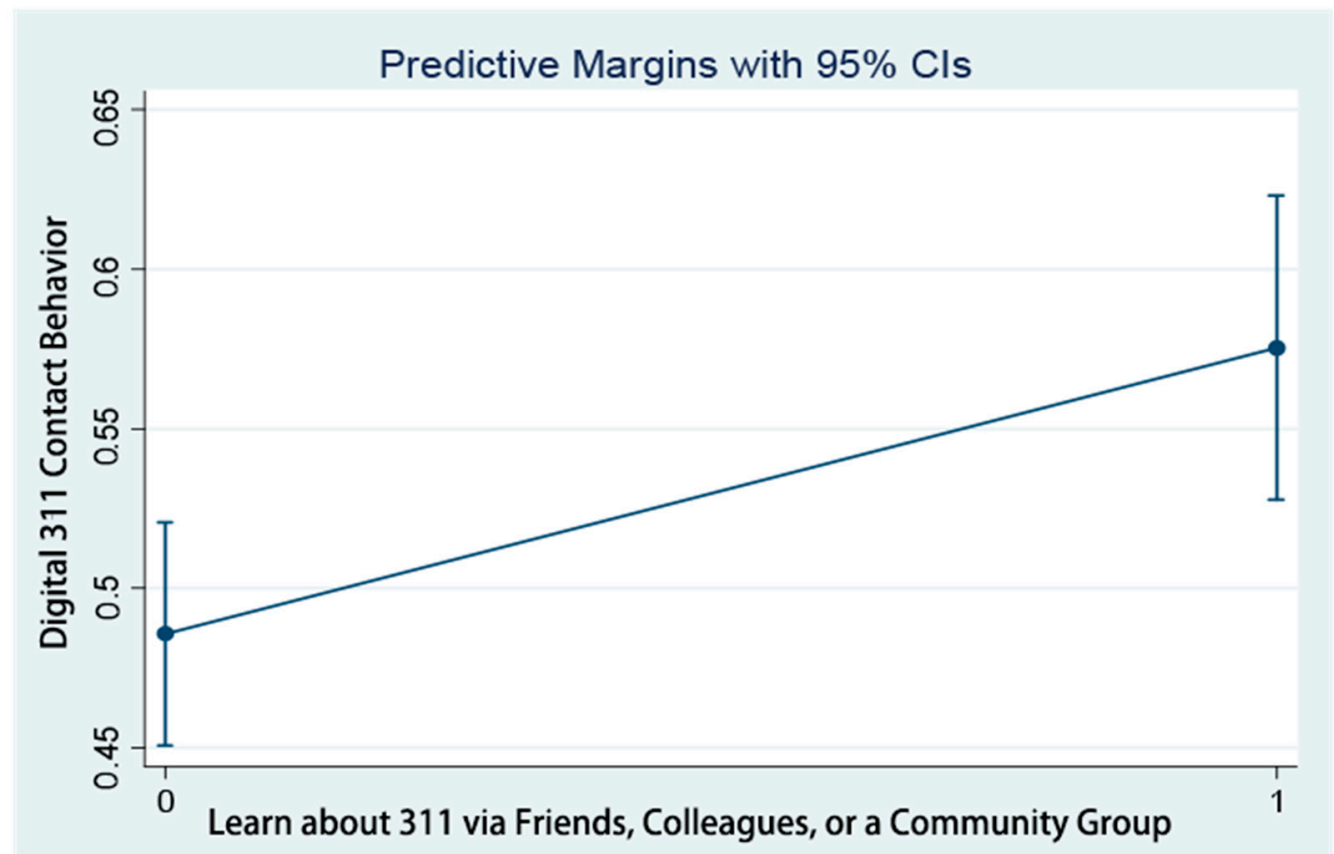

Figure 3. Estimated probabilities of digital 311 contact behavior caused by learning about 311 via friends, colleagues, and community groups.

Figure 1 shows that the average level of digital 311 contact behavior ranges from about 0.49 when the age equals " 0 " to about 0.57 when the age equals " 4 ". It is easy to tell from this figure that, as online public service use behavior (library e-services) increases, the probability of digital 311 contact behavior being a " 1 " also decreases from a probability of 0.49 to a probability of 0.57 .

Figure 2 shows that the average level of digital 311 contact behavior ranges from about 0.46 when the age equals " 0 " to about 0.71 when the age equals " 5 ". As the perception of 311 information richness 
(quantity of information sources) increases, the probability of digital 311 contact behavior being a " 1 " also decreases from a probability of 0.46 to a probability of 0.71 .

Finally, Figure 3 shows that the average level of digital 311 contact behavior ranges from about 0.49 when the age equals " 0 " to about 0.58 when the age equals " 1 ". It is easy to tell from this figure that as the degree of learning about 311 via friends, colleagues, or a community group increases, the probability of digital 311 contact behavior being a " 1 " also decreases from a probability of 0.49 to a probability of 0.58 .

\section{Discussion}

This study uses two models to assess the hypotheses in order to examine whether technology richness would delimitate digital issues in 311 contact channel choices. Channel expansion theory mainly focuses on the information richness of technology use, which is prior knowledge-building technology use experiences, and how it can explain individuals' technology use and choices. Specifically, the social influence of technology and technology richness are the two main components of channel expansion theory. Channel expansion theory also supports that technology richness decreases the digital divide. That is, when individuals have more technology use information and information sources from social influence, such as peers and friends, they experience fewer digital divide issues in technology use and choices.

In Model One, information sources related to 311 and online public service use behaviors (online library service) are significant in predicting the probability of the use of the 311 digital contact approach. In addition, channel expansion theory emphasizes the social influence of technology use and selection, and the most important influence is from peers and family (human-side social network), not the influence of social media. Model Two follows the same logic of channel expansion theory, but it compares the different sources for choosing a 311 contact channel.

Overall, this study provides significant information about 311 contact channel choices and has several significant findings. First and most importantly, there is evidence that 311 users who have more information about how to use 311 are more likely to use the digital contact approach than those who have less information, which supports Hypothesis 2 in this study. Having more information sources related to an innovative technology is a vital variable that enhances an individual's technology awareness richness and, in turn, increases the demand for innovation [51-53].

Regarding the spread of digital technology development and use, studies have asserted that whether a household has a high-speed Internet connection or not is not the main factor influencing 311 users to use a digital contact approach. Rather, the perception of 311 information richness and the information sources for technology learning play a vital role in enhancing individuals' understanding of the use of new ICTs. There is gap between the 311 digital contact approach and the 311 offline contact approach, and awareness and information sources related to 311 influence 311 users' contact channel choices. The influence of users' technology is greatly impacted by a friend, colleague, or community group. This study supports the previous studies that argue that informal social networking has a greater influence on users' acceptance of new technology approaches than user information disseminated through social media [13,43,54-56].

Online public service use behaviors have been ignored in ICT studies of public administration. Individuals would copy their online public service use behaviors in one area in others and users' habits take priority among channel choice determinates [6,55]. As in this study's Hypothesis 1, citizens' digital information use behaviors in library e-services lead the citizens to become more familiar with the digital environment and information about governmental policies and announcements, and this in turn influences their digital technology use of 311.

Public libraries' services are consumer service-oriented. This implies that citizens come to libraries based upon their willingness or need for some specific purposes, such as searching government information, seeking assistance for e-government services, accessing digital technology, and attending free technology training for governmental ICT initiatives. Local governments may consider using the 
function of local libraries to decrease technology exclusion and help individuals develop technology information-seeking behaviors in public services. Uniquely, local libraries are centrally located for digital governmental information and services, regularly and directly interacting with residents.

The cross-sectional data of this study cannot make the causal claims and it cannot generalize those findings in other cases and cities. Also, because of the second-hand survey data, this study has some limitations in building the analysis model and research design. For example, the survey only has the question about the 311 digital approach: "Have you contacted 311 by the web or a mobile device during the past year?" In this case, we do not know if the respondents used their mobile phone to call 311. In addition, the respondents who contacted 311 by the web or a mobile device (only users who contacted 311 by the web or a mobile device/used both web and offline 311 services) are all coded as 1 (used the digital approach). The 2011 San Francisco city survey data limits this study to distinguishing the difference between the citizen group who only contacted 311 by the web or a mobile device and the citizen groups who used both web and offline 311 services.

There are some significant implications for practitioners. Public managers should consider having more information sources about 311 use in order to enhance the likelihood that citizens will use a digital 311 contact approach. Public managers should develop strategies to market 311 use information and increase citizens' awareness of 311 use if they want to have more digital citizens. Also, public managers should use either e-services or governmental ICTs to advocate 311 information or to connect 311 website links to other government website pages, because citizens who have e-service information-searching behaviors are more likely to find 311 from these government website pages and click the links to 311 websites.

\section{Conclusions}

The social influence of technology and technology richness are the two main components of channel expansion theory. Channel expansion theory also supports the idea that technology richness decreases the digital divide. That is, when individuals have more technology use information and information sources from social influence, such as peers and friends, they experience fewer digital divide issues in technology use and choices. In addition, channel expansion theory emphasizes the social influence of technology use and selection, and the most important influence comes from peers and family, not social media.

Using empirical evidence from the 311 service in San Francisco to test theoretical frameworks that were originally proposed in the channel expansion theory, this study contributes to the ongoing study of citizen contact channel choices. Results indicate that, from the perspective of citizens, as household members more frequently use online government services, the likelihood of individual use of 311 digital contact approaches would increase. In addition, this study finds that learning about 311 via friends, colleagues, or a community group and the perception of 311 information richness are significant in predicting the probability of the use of a 311 digital contact approach. Digital citizenship has been the goal and the priority of many local governments.

Many local leaders should have strategies to encourage residents to use online methods and systems more, because the advantages of digital technology are expected to support government performance, decrease operational costs, and increase online citizen participation. The strategies for increasing citizens' 311 digital contact channel choices should consider citizens' digital technology use behaviors. They should also consider offering 311 use information via multiple sources. Future studies should examine strategies that account for strategic choice, multiple sources of 311 use information, and digital technology use. In addition, seeking the effective measures that capture these aspects of citizen Internet and ICT use is important to public managers because effective measures can predict citizens' 311 use.

Acknowledgments: This work was supported by the grant from the National Science Council of Taiwan (NSC 105-2410-H-110-001). 
Conflicts of Interest: The author declares no conflict of interest.

\section{References}

1. Collins, B.K.; Kim, H.J. Are satisfied citizens willing to pay more? Public sector consumerism as equitable social exchange. Public Money Manag. 2009, 29, 109-116. [CrossRef]

2. Clark, B.Y.; Brudney, J.L.; Jang, S.G. Coproduction of government services and the new information technology: Investigating the distributional biases. Public Adm. Rev. 2013, 73, 687-701. [CrossRef]

3. Khalil Moghaddam, B.; Khatoon-Abadi, A. Factors affecting ICT adoption among rural users: A case study of ICT Center in Iran. Telecommun. Policy 2013, 37, 1083-1094. [CrossRef]

4. Wang, X. Assessing public participation in US cities. Public Perform. Manag. Rev. 2001, 24, 322-336. [CrossRef]

5. Fountain, J.E. Building the Virtual State: Information Technology and Institutional Hange; Brookings Institution Press: Washington, DC, USA, 2001.

6. Reddick, C.G. Citizen interaction with e-government: From the streets to servers? Gov. Inf. Q. 2005, 22, 38-57. [CrossRef]

7. Mergel, I. A framework for interpreting social media interactions in the public sector. Gov. Inf. Q. 2013, 30, 327-334. [CrossRef]

8. Bimber, B.A. Information and American Democracy: Technology in the Evolution of Political Power; Cambridge University Press: Cambridge, UK, 2003.

9. Min, S.J. From the digital divide to the democratic divide: Internet skills, political interest, and the second-level digital divide in political internet use. J. Inf. Technol. Politics 2010, 7, 22-35. [CrossRef]

10. Morris, D.S.; Morris, J.S. Digital inequality and participation in the political process real or imagined? Soc. Sci. Comput. Rev. 2013, 31, 589-600. [CrossRef]

11. Prieger, J.E.; Hu, W.M. The broadband digital divide and the nexus of race, competition, and quality. Inf. Econ. Policy 2008, 20, 150-167. [CrossRef]

12. Dimitrova, D.V.; Chen, Y.C. Profiling the adopters of E-government information and services the influence of psychological characteristics, civic mindedness, and information channels. Soc. Sci. Comput. Rev. 2006, 24, 172-188. [CrossRef]

13. Durante, M. The online construction of personal identity through trust and privacy. Information 2011, 2, 594-620. [CrossRef]

14. Fu, K.J.; Lee, C.P. The role of trust in the prioritization of channel choices. In Electronic Government; Springer: Berlin/Heidelberg, Germany, 2014; pp. 96-105.

15. Reddick, C.G.; Turner, M. Channel choice and public service delivery in Canada: Comparing e-government to traditional service delivery. Gov. Inf. Q. 2012, 29, 1-11. [CrossRef]

16. Carlson, J.R.; Zmud, R.W. Channel expansion theory and the experiential nature of media richness perceptions. Acad. Manag. J. 1999, 42, 153-170. [CrossRef]

17. Pieterson, W.; Ebbers, W. The use of service channels by citizens in the Netherlands: Implications for multi-channel management. Int. Rev. Admin. Sci. 2008, 74, 95-110. [CrossRef]

18. Pieterson, W.J. Channel Choice: Citizens' Channel Behavior and Public Service Channel Strategy; University of Twente: Enschede, The Netherlands, 2009.

19. West, D.M. Digital Government: Technology and Public Sector Performance; Princeton University Press: Princeton, NJ, USA, 2005.

20. Schellong, A.; Mans, D. Citizens preferences towards one-stop government. In Proceedings of the 2004 Annual National Conference on Digital Government Research, Seattle, WA, USA, 24-26 May 2004; p. 11.

21. Thomas, J.C.; Streib, G. The new face of government: Citizen-initiated contacts in the era of E-government. J. Public Admin. Res. Theory 2003, 13, 83-102. [CrossRef]

22. Reddick, C.G. Citizen-initiated contacts with government: Comparing phones and websites. J. E-Gov. 2005, 2, 27-53. [CrossRef]

23. Ebbers, W.E.; Pieterson, W.J.; Noordman, H.N. Electronic government: Rethinking channel management strategies. Gov. Inf. Q. 2008, 25, 181-201. [CrossRef]

24. Teerling, M.L.; Pieterson, W. Multichannel marketing: An experiment on guiding citizens to the electronic channels. Gov. Inf. Q. 2010, 27, 98-107. [CrossRef] 
25. Reddick, C.G.; Abdelsalam, H.M.; Elkadi, H.A. Channel choice and the digital divide in E-government: The case of Egypt. Inf. Technol. Dev. 2012, 18, 226-246. [CrossRef]

26. Hung, M.J. Building citizen-centred E-government in Taiwan: Problems and prospects. Aust. J. Public Admin. 2012, 71, 246-255. [CrossRef]

27. O'Brien, D.T. Custodians and custodianship in urban neighborhoods: A methodology using reports of public issues received by a city's 311 hotline. Environ. Behav. 2015, 47, 304-327. [CrossRef]

28. Haddon, L. Social exclusion and information and communication technologies lessons from studies of single parents and the young elderly. New Media Soc. 2000, 2, 387-406. [CrossRef]

29. van Deursen, A.; Pieterson, W. The Internet as a service channel in the public sector. In Proceedings of the ICA Conference, Dresden, Germany, 19-23 June 2006.

30. Susanto, T.D.; Goodwin, R. User acceptance of SMS-based e-government services: Differences between adopters and non-adopters. Gov. Inf. Q. 2013, 30, 486-497. [CrossRef]

31. D'Urso, S.C.; Rains, S.A. Examining the scope of channel expansion: A test of channel expansion theory with new and traditional communication media. Manag. Commun. Q. 2008, 21, 486-507. [CrossRef]

32. Enoch, Y.; Soker, Z. Age, gender, ethnicity and the digital divide: University students' use of web-based instruction. Open Learn. 2006, 21, 99-110. [CrossRef]

33. Wu, W.N.; Jung, K. A missing link between citizen participation, satisfaction, and public performance: Evidences from the city and county of San Francisco. Int. J. Public Sect. Perform. Manag. 2016, 2, 392-410. [CrossRef]

34. Rogers, E.M. Diffusion of Innovations; Simon and Schuster: New York, NY, USA, 2010.

35. Thomas, J.C. Citizen, Customer, Partner: Engaging the Public in Public Management; ME Sharpe: Armonk, NY, USA, 2012.

36. Jaeger, P.T.; Bertot, J.C. Transparency and technological change: Ensuring equal and sustained public access to government information. Gov. Inf. Q. 2010, 27, 371-376. [CrossRef]

37. Walton, P. Digital Information and Value. Information 2015, 6, 733-749. [CrossRef]

38. Jackson, L.A.; Zhao, Y.; Kolenic, A., III; Fitzgerald, H.E.; Harold, R.; Von Eye, A. Race, gender, and information technology use: The new digital divide. CyberPsychol. Behav. 2008, 11, 437-442. [CrossRef] [PubMed]

39. Robinson, J.P.; DiMaggio, P.; Hargittai, E. New social survey perspectives on the digital divide. It Soc. 2003, 1, 1-22.

40. van Dijk, J.A. Digital divide research, achievements and shortcomings. Poetics 2006, 34, 221-235. [CrossRef]

41. Servon, L.J. Bridging the Digital Divide: Technology, Community and Public Policy; John Wiley \& Sons: Hoboken, NJ, USA, 2008.

42. Walther, J.B. Theories of computer-mediated communication and interpersonal relations. Handb. Interpers. Commun. 2011, 4, 443-479.

43. Carlson, J.R.; George, J.F. Media appropriateness in the conduct and discovery of deceptive communication: The relative influence of richness and synchronicity. Group Decis. Negot. 2004, 13, 191-210. [CrossRef]

44. Hill, R.; Beynon-Davies, P.; Williams, M.D. Older people and internet engagement: Acknowledging social moderators of internet adoption, access and use. Inf. Technol. People 2008, 21, 244-266. [CrossRef]

45. Berger, P.; Trexler, S. Choosing Web 2.0 Tools for Learning and Teaching in A Digital World; Libraries Unlimited, Inc.: Englewood, CO, USA, 2010.

46. Chen, Y.C.; Dimitrova, D.V. Electronic government and online engagement: Citizen interaction with government via web portals. Int. J. Electron. Gov. Res. 2006, 2, 54-76. [CrossRef]

47. Nisbet, E.C.; Stoycheff, E.; Pearce, K.E. Internet use and democratic demands: A multinational, multilevel model of Internet use and citizen attitudes about democracy. J. Commun. 2012, 62, 249-265. [CrossRef]

48. Kavanaugh, A.; Sheetz, S.D.; Hassan, R.; Yang, S.; Elmongui, H.G.; Fox, E.A.; Shoemaker, D.J. Between a rock and a cell phone: Communication and information technology use during the 2011 Egyptian uprising. In Proceedings of the 2012 Information Systems for Crisis Response and Management Conference, Vancouver, BC, Canada, 22-25 April 2012.

49. Fulk, J.; Schmitz, J.; Ryu, D. Cognitive elements in the social construction of communication technology. Manag. Commun. Q. 1995, 8, 259-288. [CrossRef]

50. Cuillier, D.; Piotrowski, S.J. Internet information-seeking and its relation to support for access to government records. Gov. Inf. Q. 2009, 26, 441-449. [CrossRef]

51. Nam, T. Determining the type of e-government use. Gov. Inf. Q. 2014, 31, 211-220. [CrossRef] 
52. Alawneh, A.; Al-Refai, H.; Batiha, K. Measuring user satisfaction from e-Government services: Lessons from Jordan. Gov. Inf. Q. 2013, 30, 277-288. [CrossRef]

53. Alomari, M.; Woods, P.; Sandhu, K. Predictors for e-government adoption in Jordan: Deployment of an empirical evaluation based on a citizen-centric approach. Inf. Technol. People 2012, 25, 207-234. [CrossRef]

54. George, J.F.; Carlson, J.R.; Valacich, J.S. Media selection as a strategic component of communication. MIS Q. 2013, 37, 1233-1251.

55. Kupritz, V.W.; Hillsman, T. The impact of the physical environment on supervisory communication skills transfer. J. Bus. Commun. 2011, 48, 148-185. [CrossRef]

56. Jung, K.; Park, S.J.; Wu, W.N.; Park, H.W. A webometric approach to policy analysis and management using exponential random graph models. Qual. Quant. 2015, 49, 581-598. [CrossRef]

(C) 2017 by the author; licensee MDPI, Basel, Switzerland. This article is an open access article distributed under the terms and conditions of the Creative Commons Attribution (CC-BY) license (http:/ / creativecommons.org/licenses/by/4.0/). 